\title{
Preparation and Properties Study of Cr on FeCrAl Cladding Materials
}

\author{
Peng Wang ${ }^{1}$, Yingjie Qiao ${ }^{1}$, Wen $Q i^{1}$, Shiyu ${ }^{1,2}{ }^{1,2}$, Zhen Liu ${ }^{1,2}$, Fanping Meng ${ }^{2}$, \\ Xiaohong Zhang ${ }^{1}$, Kun Wang ${ }^{1}$, Qiuwu $\mathrm{Li}^{1}{ }^{1}$, Zhaoding Yao ${ }^{1}$, Chengying Bai ${ }^{1}$ and \\ XiaoDong Wang ${ }^{1 *}$
}

${ }^{1}$ College of Materials Science and Chemical Engineering, Harbin Engineering University, Harbin, China, ${ }^{2}$ Engineering Laboratory of Advanced Energy Materials, Ningbo Institute of Industrial Technology, Chinese Academy of Sciences, Ningbo, China

FeCrAl alloy is a promising candidate material for the fourth-generation reactor core cladding material. Adjustment of the $\mathrm{Cr}$ content is one of the effective ways to obtain enhanced performance for the FeCrAl alloy. In this work, Fe- $x$ Cr-6Al alloy $(11 \leq x \leq 15)$ with different $\mathrm{Cr}$ content were successfully prepared by hot rolling. When $\mathrm{Cr}$ replacement of $\mathrm{Fe}$ atoms in $\mathrm{Fe}-x \mathrm{Cr}-6 \mathrm{Al}$ alloy rises from 11 to $15 \mathrm{wt} \%$, the lattice distortion of $\mathrm{Fe}-x \mathrm{Cr}-6 \mathrm{Al}$ alloy increases, and the mechanical properties and thermal conductivity of the $\mathrm{Fe}-x \mathrm{Cr}-6 \mathrm{Al}$ alloy are raised. Compared with $\mathrm{Al}$ content, $\mathrm{Cr}$ content has less effect on $\mathrm{Fe}-x \mathrm{Cr}-6 \mathrm{Al}$ oxidation resistance.

\section{OPEN ACCESS}

Edited by: Liqiang Wang,

Shanghai Jiao Tong University, China

Reviewed by:

Liang-Yu Chen,

Jiangsu University of Science and

Technology, China

Hung-Wei Yen,

National Taiwan University, Taiwan

*Correspondence:

XiaoDong Wang

wangxiaodong@hrbeu.edu.cn

Specialty section:

This article was submitted to Structural Materials, a section of the journal Frontiers in Materials

Received: 25 October 2020 Accepted: 08 February 2021 Published: 25 March 2021

Citation:

Wang P, Qiao Y, Qi W, Du S, Liu Z, Meng F, Zhang X, Wang K, Li Q, Yao Z, Bai $C$ and Wang $X$ (2021) Preparation and Properties Study of Cr on FeCrAl

Cladding Materials.

Front. Mater. 8:621086.

doi: 10.3389/fmats.2021.621086
Keywords: FeCrAl alloy, thermal performance, mechanical behavior, high-temperature steam oxidation, micro structure

\section{INTRODUCTION}

In recent years, with the potential shortage of traditional energy sources, nuclear power has become increasingly important (Farmer et al., 2014). However, with the occurrence of some well-known nuclear accidents, people have realized that the second and third generation nuclear energy systems in operation would hardly meet the safety requirements and the development of fourth-generation nuclear energy systems is in demand (Guzonas and Novotny, 2014; Yamamoto et al., 2015; Gong et al., 2016). And at present, operating temperature of the typical light water reactor (LWR) in the third-generation nuclear reactor is $285-320^{\circ} \mathrm{C}$, while the core outlet pressure and temperature of the supercritical water-cooled reactor (SCWR), which is the fourth-generation nuclear reactor and also adopts light water as the coolant, can be $25 \mathrm{MPa}$ and $620-650^{\circ} \mathrm{C}$ (MacDonald et al., 2005). As the first barrier for nuclear safety protection, the reliability of fuel cladding plays a key role. In the nuclear accident at Fukushima Nuclear Power Plant in Japan in 2011, the Zr alloy cladding was rapidly oxidized under the loss of coolant accident (LOCA) conditions at $1,200^{\circ} \mathrm{C}$, resulting in damage to the core and a hydrogen explosion (Pint et al., 2015).

Subsequently, the researchers conducted a series of investigations on the corrosion mechanism of commercial zirconium alloys, and found the corrosion weight gain of $\mathrm{Zr}-1 \mathrm{Nb}$ and $\mathrm{Zr}-\mathrm{Sn}-\mathrm{Nb}$ in $\mathrm{LiOH}$ aqueous solution at $360^{\circ} \mathrm{C} / 18.6 \mathrm{MPa}$ are $0.4-0.8 \mathrm{mg} / \mathrm{mm}^{2}$ during 200 -days exposure (Chen et al., 2015, 2016, 2018). And the oxidation weight gains of commercial zirconium alloy like Zry-4, D4, M5, E110 and Zirlo in $600^{\circ} \mathrm{C}$ high temperature water vapor are $2-10 \mathrm{mg} / \mathrm{cm}^{2} \mathrm{~h}$ during $45 \mathrm{~h}$ exposure. But as the oxidation temperature increases, the oxidation weight gains of commercial zirconium alloy like Zry-4, D4, M5, E110 and Zirlo in $1,200^{\circ} \mathrm{C}$ high temperature water vapor are $50-80 \mathrm{mg} / \mathrm{cm}^{2} \mathrm{~h}$ (Steinbrück et al., 2011). Therefore, it is difficult to adopt the current commercial $\mathrm{Zr}$ alloys as claddings in the fourth-generation nuclear reactors, which call for novel materials to replace Zircaloy with higher tolerance under extreme conditions. Recently, the $\mathrm{FeCrAl}$ ferritic alloy attracts 
attention due to its excellent oxidation resistance, and quickly become one of the candidate materials for the fourth-generation nuclear energy system cladding (Dryepondt et al., 2018).

The nuclear fuel cladding is not only a protective layer between the nuclear fuel and the coolant, but also provides the necessary structural support for the nuclear fuel. (Chang et al., 2019). For this reason, the desired cladding materials should provide sufficient strength and oxidation resistance to ensure that it can last a long time in the LOCA conditions (Zinkle et al., 2014; Konings et al., 2015; Gamble et al., 2017). For the performance of $\mathrm{FeCrAl}$ alloy, researchers have reported plenty of studies on their oxidation resistance (Field et al., 2015; Yamamoto et al., 2015; Aghamiri et al., 2020). the oxidation weight gain of $\mathrm{FeCrAl}$ alloy is much lower than this value (Pan et al., 2016; Maeda et al., 2019; Qiao et al., 2020). However, challenge persists for reliability of FeCrAl alloys in a harsh environment, e.g. in a supercritical water-cooled reactor where the operating temperature may exceed $380^{\circ} \mathrm{C}$ and the enthalpy for the reaction between the nuclear fuel cladding material and supercritical water is increased (Naidin et al., 2009).

As the cladding of nuclear fuel suffers from the internal pressure caused by the swelling, investigations have been performed on the factors affecting the mechanical properties (Yano et al., 2017; Sun et al., 2018; Kim et al., 2019; Yang et al., 2020) as well as the thermal conductivities of the FeCrAl alloy (Niu et al., 2008; Liu et al., 2017). In the meantime, the influence of main element content on thermomechanical performances are also concerned on. He et al. (2018) used industrial pure metals $\mathrm{Fe}, \mathrm{Cr}$ and $\mathrm{Al}$ for vacuum induction smelting, and prepared $25 \mathrm{~kg} \mathrm{FeCrAl}$ alloy ingots with different $\mathrm{Al}$ contents. Their results show that the prepared $\mathrm{FeCrAl}$ alloy exists as a body-centered cubic solid solution of $\mathrm{a}-\mathrm{Fe}(\mathrm{Cr}, \mathrm{Al})$ in which $\mathrm{Cr}$ and $\mathrm{Al}$ are dissolved in $\mathrm{Fe}$. The ferrite phase remains stable before and after the high temperature tensile test. At all temperatures, the peak stress and yield stress increase with the increase of $\mathrm{Al}$ content, resulting from $\mathrm{Al}$ solid solution strengthening. Additionally, Young's modulus decreases with the increase of Al content. Qiu et al. (2018) found that the thermal conductivity of C35M and $\mathrm{Zr} 4$ alloy is similar, while the specific heat capacity of $\mathrm{C} 35 \mathrm{M}$ alloy is higher than that of $\mathrm{Zr} 4$ alloy. Field et al. (2015) prepared four $\mathrm{FeCrAl}$ alloys with different $\mathrm{Cr}$ and $\mathrm{Al}$ content added by arc smelting. Then, the FeCrAl alloy samples were prepared by hot forging, hot rolling and heat treatment, which were used for irradiation experiments. It is found that the samples with low $\mathrm{Cr}$ content have no brittle fracture phenomenon after irradiated above 7.0 dpa when FeCrAl alloy is irradiated in the LWR operating temperature range. In addition, compared with traditional $\mathrm{Zr}$-based alloys, $\mathrm{FeCrAl}$ alloy samples with low $\mathrm{Cr}$ content still retain sufficient tensile properties after neutron irradiation. However, when the content of $\mathrm{Cr}$ is within the composition range that is difficult to produce a phase (Dryepondt et al., 2018), its influence on the structure and mechanical properties of $\mathrm{FeCrAl}$ alloy still needs further study. Furthermore, it was also found $\mathrm{Cr}$ in $\mathrm{FeCrAl}$ alloy can participate in oxidation reaction at high temperature and affect the oxidation resistance of the cladding material (Niu et al., 2008). Therefore, more investigations are necessary to understand the effect of $\mathrm{Cr}$ on the high temperature water vapor oxidation resistance of the FeCrAl alloy, and control the production of its a phase at the
TABLE 1 | Chemical compositions of experimental of Fe-Cr-Al alloy (wt\%).

\begin{tabular}{lcccc}
\hline Experimental alloys & Fe & Cr & Al & C \\
\hline Fe-11Cr-6Al & 82.98 & 11.11 & 5.90 & 0.0080 \\
Fe-12Cr-6Al & 82.08 & 12.01 & 5.90 & 0.0068 \\
Fe-13Cr-6Al & 81.19 & 12.89 & 5.91 & 0.0085 \\
Fe-14Cr-6Al & 79.83 & 14.20 & 5.96 & 0.0073 \\
Fe-15Cr-6Al & 78.94 & 15.06 & 5.99 & 0.0066
\end{tabular}

same time. Considering the arguments outlined above, we have prepared different $\mathrm{Fe}-x \mathrm{Cr}-6 \mathrm{Al}$ alloys $(11 \leq x \leq 15)$ with $11-15 \mathrm{wt} \%$ $\mathrm{Cr}$ in this work to understand their composition-structure-propertyperformance relationships. Through analyzing the influence of $\mathrm{Cr}$ content on the mechanical properties, thermal performance and oxidation resistance of alloys, the current study may provide technical reference for the development of advanced nuclear energy system materials in future studies.

\section{EXPERIMENTAL PROCEDURES}

\section{Materials}

In this study, five $\mathrm{Fe}-\mathrm{Cr}-\mathrm{Al}$ alloys with different $\mathrm{Cr}$ contents were designed, named as Fe-11Cr-6Al, Fe-12Cr-6Al, Fe-13Cr-6Al, $\mathrm{Fe}-14 \mathrm{Cr}-6 \mathrm{Al}$ and $\mathrm{Fe}-15 \mathrm{Cr}-6 \mathrm{Al}$, respectively. The pure $\mathrm{Fe}$ [99.50wt\% (Weight percent)], pure $\mathrm{Cr}(99.00 \mathrm{wt} \%)$ and pure $\mathrm{Al}$ (99.60wt\%) were used to prepare the $\mathrm{Fe}-x \mathrm{Cr}-6 \mathrm{Al}$ alloy $(11 \leq x \leq$ 15). The $\mathrm{Fe}-x \mathrm{Cr}-6 \mathrm{Al}$ ingots with weight of $20 \mathrm{~kg}$ were obtained by vacuum induction melting (VIM) (Song et al., 2018). Then the ingots were homogenized at $1,150^{\circ} \mathrm{C}$ for $3 \mathrm{~h}$, and then hot rolled to $16 \mathrm{~mm}$ in thickness at $800^{\circ} \mathrm{C}$, finally annealed at $1,000^{\circ} \mathrm{C}$ for $1 \mathrm{~h}$. The composition of $\mathrm{Fe}-\mathrm{Cr}-\mathrm{Al}$ alloy ingots were measured by Inductively Coupled Plasma Optical Emission Spectrometer (ICAP-6300) and carbon analyzer (HW2000B). The detection limits for ICAP-6300 and HW2000B are 0.01-99.99 and 0.0001-99.9999wt\% and the results are listed in Table 1.

\section{Experimental Setup}

$\mathrm{X}$-ray diffraction (XRD) measurements of $\mathrm{Fe}-x \mathrm{Cr}-6 \mathrm{Al}$ alloy were performed using a D8 Advance X-ray diffractometer with a CuKa source $(\lambda=1.540,598 \AA)$. Surface morphologies were characterized by a Phenom Pure scanning electron microscope (SEM). Metallographic organization were characterized by a metallographic optical microscope. The HVS-1000A digital microhardness tester was used to test the microhardness of $\mathrm{Fe}-x \mathrm{Cr}-6 \mathrm{Al}$ alloy. The ES310D density balance was used to test the room temperature density of $\mathrm{Fe}-x \mathrm{Cr}-6 \mathrm{Al}$ alloy. Compression sample was $10 \mathrm{~mm} \times 10 \mathrm{~mm} \times 30 \mathrm{~mm}$. Compression tests were conducted using shoulder loading at a crosshead speed of $2 \mathrm{~mm} / \mathrm{min}$ with WDW-100 mechanical testing machine. The engineering stress was calculated by dividing the applied load by the initial cross-sectional area. All compression tests were performed at room temperature.

The oxidation experiments were conducted with reference to ISO 102700 and GBT 13303-1991. Initially, the $\mathrm{Al}_{2} \mathrm{O}_{3}$ crucible was roasted at $1,200^{\circ} \mathrm{C}$ until the weight change was less than $0.0001 \mathrm{mg}$, and the $\mathrm{Fe}-\mathrm{Cr}-\mathrm{Al}$ alloy sample with the size of $20 \mathrm{~mm}$ 


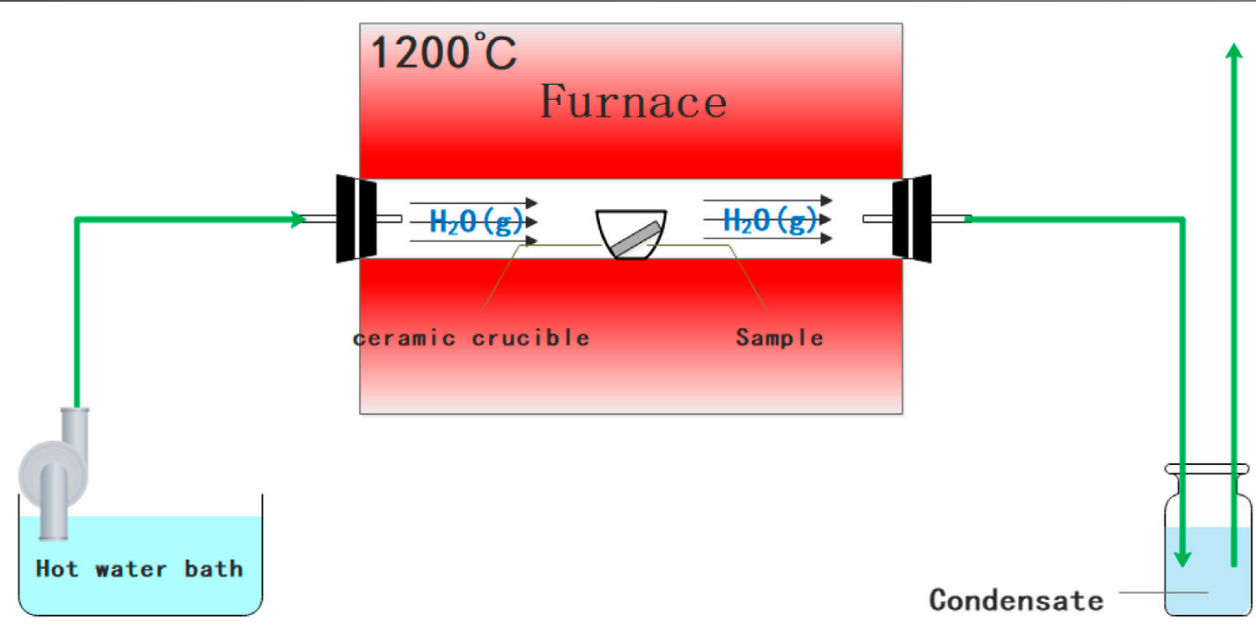

FIGURE 1 | Schematic diagram of a controlled environment fireside corrosion test setup (Qiao et al., 2020).

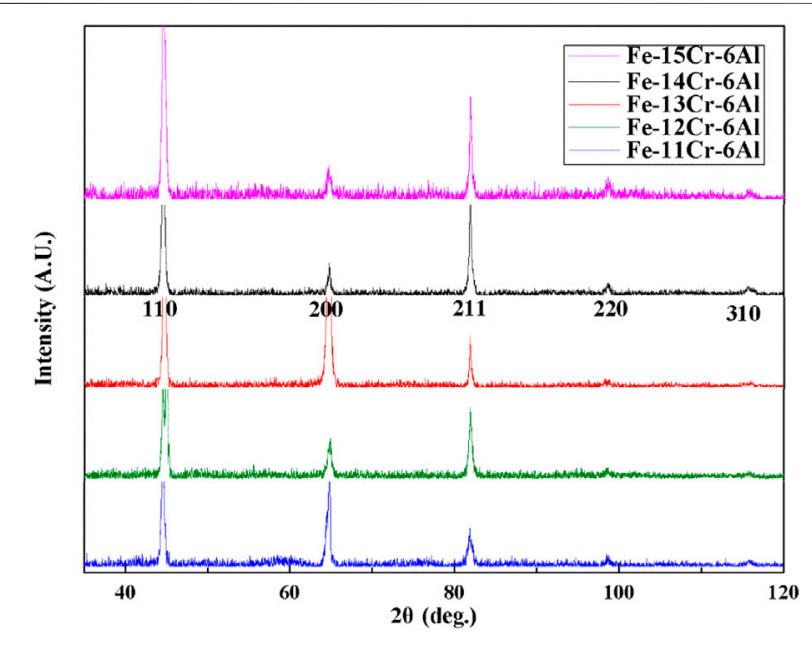

FIGURE 2 | X-ray diffraction patterns of Fe- $x \mathrm{Cr}-6 \mathrm{Al}$ with different compositions.

$\times 10 \mathrm{~mm} \times 3 \mathrm{~mm}$ was polished to 2,000 mesh and then put into the vacuum atmosphere tube furnace (SLG-1400C) by leaning in the crucible. After the sample was placed stably, the steam evaporator feed pump was turned on and ran for $5 \mathrm{~min}$. After the air was discharged from the heating pipe, the heating device was switched to $1,200^{\circ} \mathrm{C}$ at $20^{\circ} \mathrm{C} / \mathrm{min}$ and then kept for $4 \mathrm{~h}$. After cooling to room temperature, the total weight of the crucible and the sample was weighed. The schematic diagram of the experimental device is shown in Figure 1 (Qiao et al., 2020).

The FeCrAl alloy sample for thermal conductivity test is a cylindrical sheet with a size of $\Phi 12.7 \mathrm{~mm} \times 3 \mathrm{~mm}$. The testing equipment is a laser thermal conductivity meter LFA457. The coefficient of thermal expansion (CTE), of $\mathrm{Fe}-x \mathrm{Cr}-6 \mathrm{Al}$ alloy in the range of $40-400^{\circ} \mathrm{C}$ is characterized. The test sample size of CTE test is $\Phi 10 \mathrm{~mm} \times 20 \mathrm{~mm}$, and the testing equipment is L75 Platinum Series thermal expansion meter.

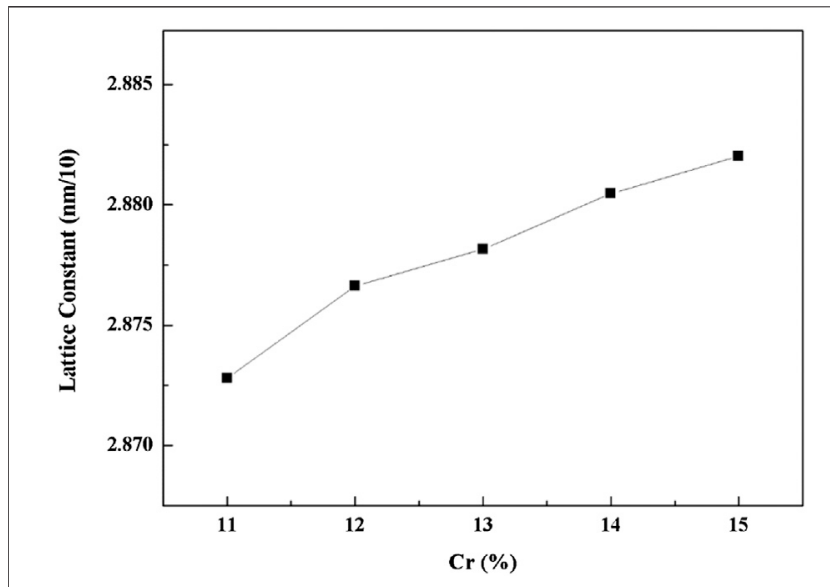

FIGURE 3 | Average composition-lattice constant curve of $\mathrm{Fe}-x \mathrm{Cr}-6 \mathrm{Al}$ alloy in room temperature.

\section{RESULTS AND DISCUSSIONS}

The microstructure and macroscopic properties of the alloy are often affected by the types and contents of the elements in the alloy. Therefore, analyzing the influence of elements on the properties of the alloy can help better design the cladding alloy system (Huczkowski et al., 2015; Sun et al., 2017). By analyzing the influence of Cr content on the microstructure morphology, micromechanical properties, oxidation resistance and thermal properties of $\mathrm{Fe}-x \mathrm{Cr}-6 \mathrm{Al}$ series alloys (11 $\leq x \leq 15)$, the relationships of composition-structureproperty-performance can be obtained.

\section{Microstructure Observations of Fe-xCr-6Al Cladding Materials}

[The phase analysis of the rolled $\mathrm{Fe}-x \mathrm{Cr}-6 \mathrm{Al}$ alloy sample by $\mathrm{X}$-ray diffractometer is shown in Figure 2. The crystal structure of $\mathrm{Fe}-\mathrm{Cr}-\mathrm{Al}$ alloy belongs to the Fe-Cr phase (PDF \#54-0331, Space Group Im- 


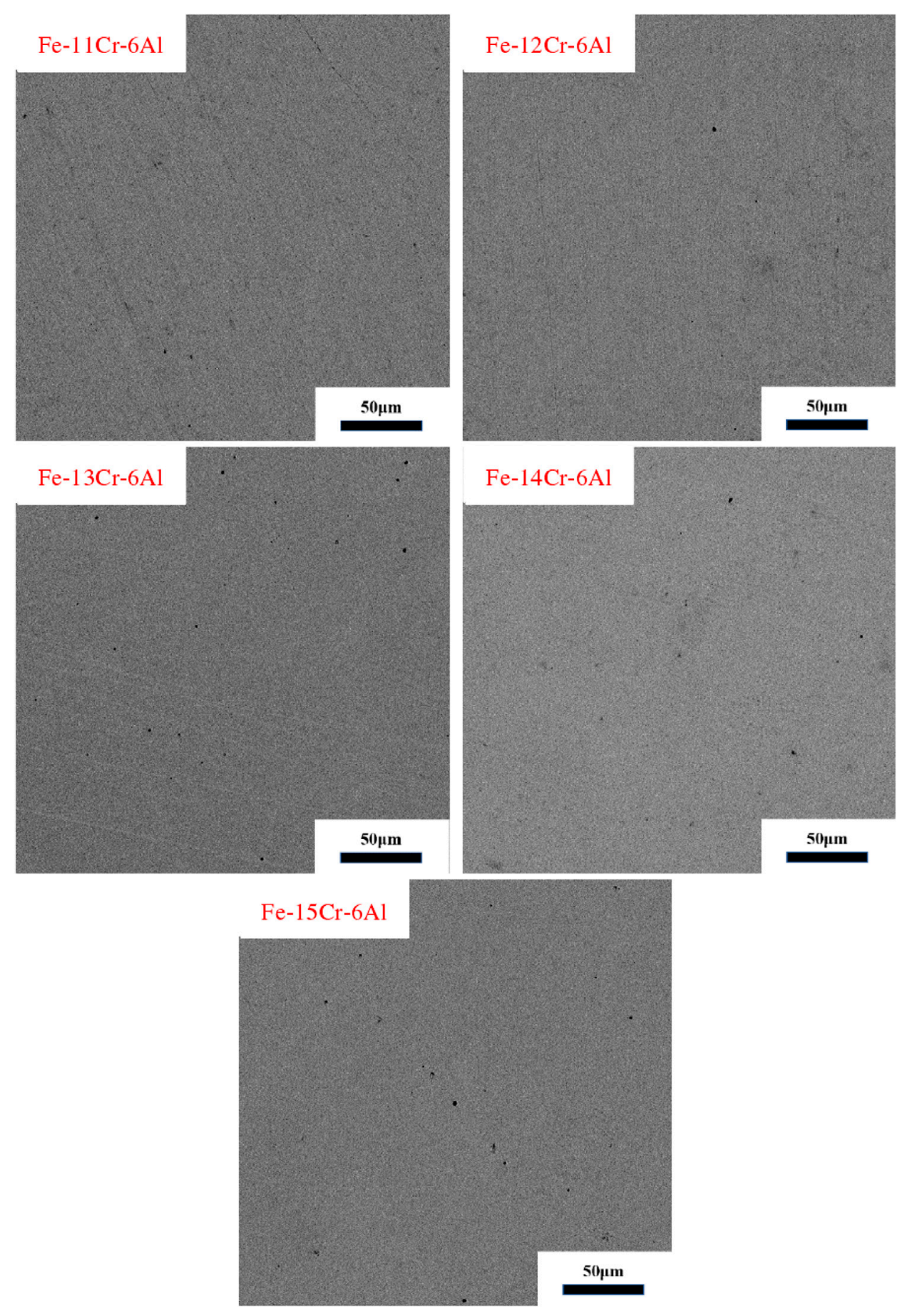

FIGURE 4 | As-cast Fe-13Cr-6Al alloy before metallographic surface treatment.

$3 \mathrm{~m}$, No.229). At the same time, its peak width includes $\mathrm{Fe}, \mathrm{CrFe}_{3}$, $\mathrm{CrFe}, \mathrm{Cr}_{2} \mathrm{Fe}, \mathrm{Cr}_{3} \mathrm{Fe}$ and some other $\mathrm{Fe}-\mathrm{Cr}$ structures. Since the test sample is in a bulk form, the crystal orientation of the samples will affect the absolute strength of XRD which makes the peak intensities varying from one alloy to another, but impact little on peak position. At the same time, the noise value of the XRD in this test is about 3\%, which means no observable second phase was formed within the samples and no impurity that can cause notable influence was introduced with the increasing $\mathrm{Cr}$ content in the $\mathrm{Fe}-x \mathrm{Cr}-6 \mathrm{Al}$ alloy.

$$
2 d \cdot \sin \theta=n \cdot \lambda
$$

The lattice constants of $\mathrm{Fe}-x \mathrm{Cr}-6 \mathrm{Al}$ alloys with different $\mathrm{Cr}$ content can be obtained by the Bragg formula written as Eq. 1 

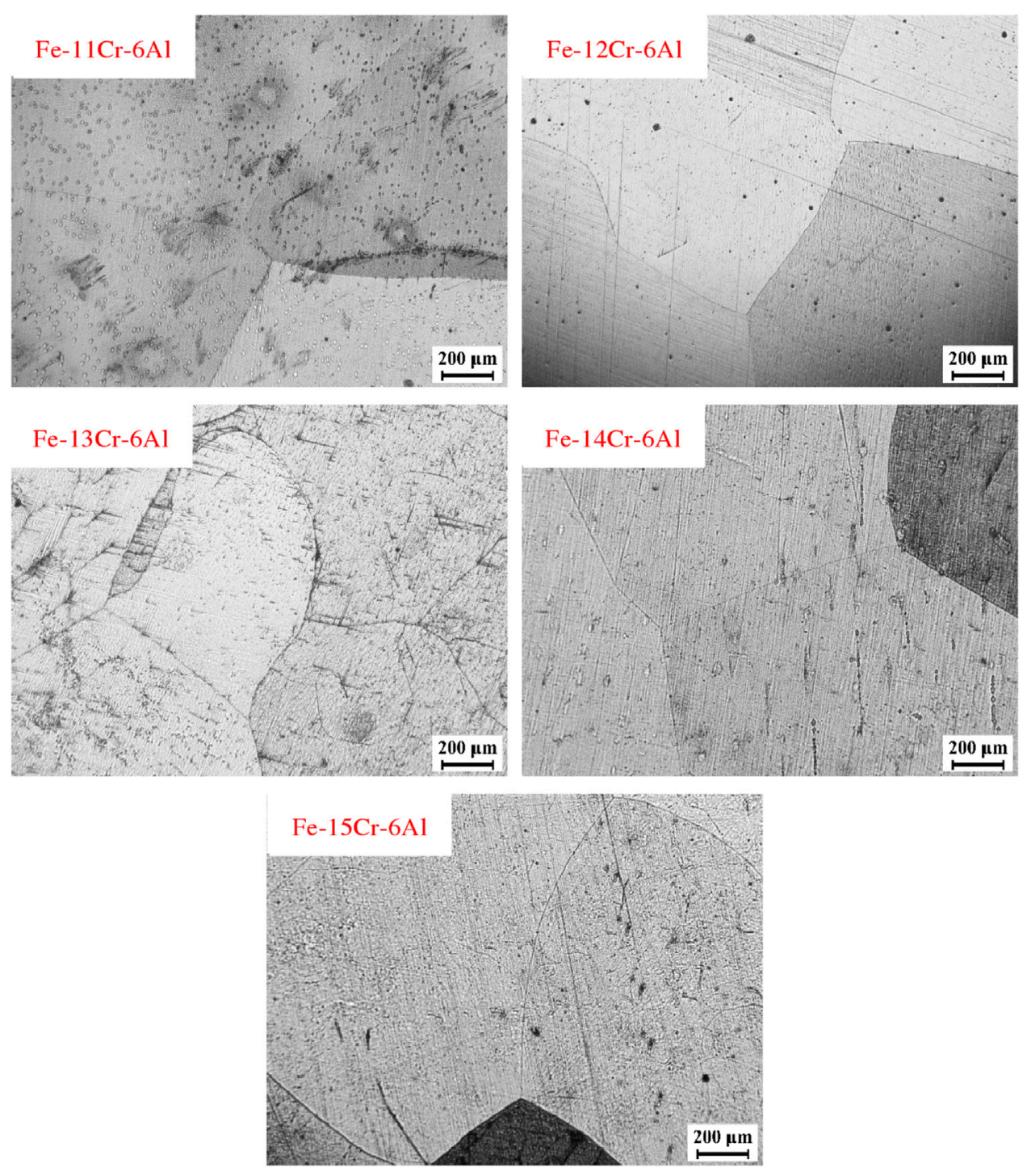

FIGURE 5 | As-cast structure of $\mathrm{Fe}-x \mathrm{Cr}-6 \mathrm{Al}$ alloy with different $\mathrm{Cr}$ content.

(Saowadee et al., 2017). In Eq. 1, $d$ is the interplanar distance of the $\mathrm{Fe}-x \mathrm{Cr}-6 \mathrm{Al}$ alloys; $\theta$ is the angle between the incident $\mathrm{X}$-ray and the corresponding crystal plane; $\lambda$ is the $X$-ray wavelength; $n$ is the diffraction order, usually set to 1 . Since $\mathrm{Fe}-x \mathrm{Cr}-6 \mathrm{Al}$ alloys are body-centered cubic, its lattice constant is 2 days. The composition-lattice constant curve of the $\mathrm{Fe}-x \mathrm{Cr}-6 \mathrm{Al}$ alloy $\{2$ 00 \} crystal planes, as shown in Figure 3. It is found that the unit cell distorted with the increase of $\mathrm{Cr}$ content, and the lattice constant of $\mathrm{Fe}-x \mathrm{Cr}-6 \mathrm{Al}$ alloy increases. And $\alpha$-Fe atomic radius is $0.1241 \mathrm{~nm}, \alpha-\mathrm{Cr}$ atomic radius is $0.1249 \mathrm{~nm}$. When $\mathrm{Cr}$ content in $\mathrm{Fe}-x \mathrm{Cr}-6 \mathrm{Al}$ alloy increases, the unit cell of the alloy is expanded, making the unit cell size of the $\mathrm{Fe}-x \mathrm{Cr}-6 \mathrm{Al}$ alloy increase, and leading in the distortion of its crystal structure increase.

Figure 4 shows the as-cast $\mathrm{Fe}-13 \mathrm{Cr}-6 \mathrm{Al}$ alloy before metallographic corrosion. The surface morphology can be found in good homogeneity and there is no precipitation of carbides or other inclusions, although there are some small pores on the surface of the alloy, which may be produced during the casting process.

Figure 5 shows the grain structure of the columnar crystal region for the as-cast $\mathrm{FeCrAl}$ alloy after metallographic surface treatment. With the $\mathrm{Cr}$ content of the $\mathrm{Fe}-x \mathrm{Cr}-6 \mathrm{Al}$ alloy increasing from 11 to $15 \mathrm{wt} \%$, the grain size of the columnar crystal region for the as-cast $\mathrm{Fe}-x \mathrm{Cr}-6 \mathrm{Al}$ alloy fluctuates from 1,000 to $1,500 \mu \mathrm{m}$. At the same time, it can be found that the micropores on the surface expanded after metallographic surface treatment.

Figure 6 shows the grain size of $\mathrm{Fe}-x \mathrm{Cr}-6 \mathrm{Al}$ alloy recrystallization annealed at $1,000^{\circ} \mathrm{C}$ for $60 \mathrm{~min}$ after metallographic surface treatment. the observation shows that the $\mathrm{Fe}-x \mathrm{Cr}-6 \mathrm{Al}$ alloy has been completely recrystallized. And When 

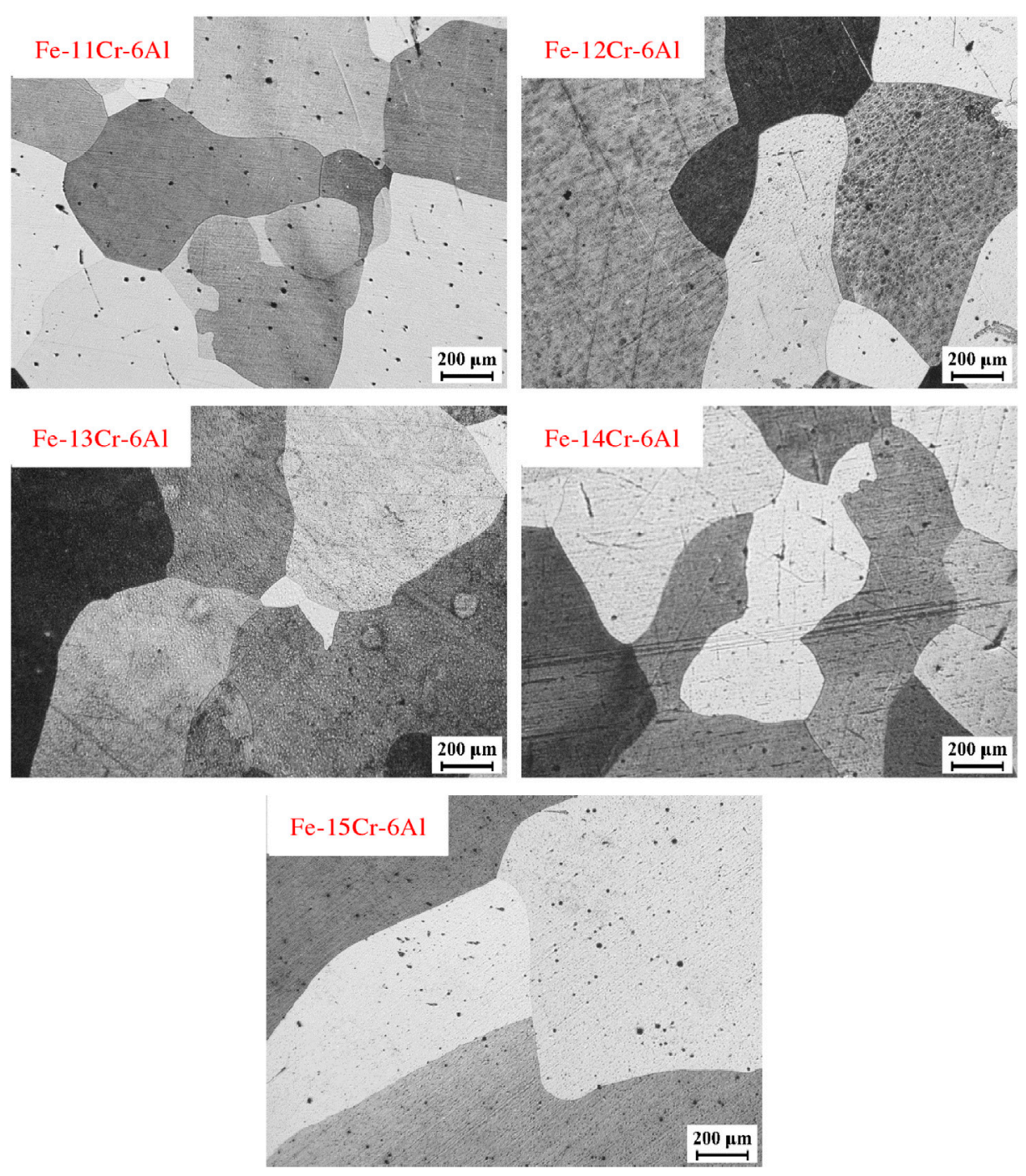

FIGURE 6 | Recrystallization and annealing structure of Fe- $x \mathrm{Cr}-6 \mathrm{Al}$ alloys with different $\mathrm{Cr}$ content after rolling

the $\mathrm{Cr}$ content of $\mathrm{Fe}-x \mathrm{Cr}-6 \mathrm{Al}$ alloy varies from $11 \mathrm{wt} \%$ to $15 \mathrm{wt} \%$, the grain size of $\mathrm{Fe}-x \mathrm{Cr}-6 \mathrm{Al}$ alloy fluctuates from 300 to $550 \mu \mathrm{m}$.

\section{Mechanical Properties of $\mathrm{Fe}-x \mathrm{Cr}-6 \mathrm{Al}$ Cladding Materials}

Figure 7 shows the density of $\mathrm{Fe}-x \mathrm{Cr}-6 \mathrm{Al}$ series alloys at room temperature. When the $\mathrm{Al}$ content is unchanged and the $\mathrm{Cr}$ atoms replace the $\mathrm{Fe}$ atoms in the $\mathrm{Fe}-x \mathrm{Cr}-6 \mathrm{Al}$ alloy with $11 \mathrm{wt} . \%$ $15 \mathrm{wt} \%$, the density of the $\mathrm{Fe}-x \mathrm{Cr}-6 \mathrm{Al}$ alloy decreases. The relative atomic mass of $\mathrm{Cr}$ element is $51.996 \mathrm{~g} / \mathrm{mol}$, while that of Fe element is $55.845 \mathrm{~g} / \mathrm{mol}$. Therefore, when the content of Al element remains unchanged, the replacement of $\mathrm{Fe}$ atoms in $\mathrm{Fe}-x \mathrm{Cr}-6 \mathrm{Al}$ alloy with $11-15 \mathrm{wt} \%$ of $\mathrm{Cr}$ atoms will result in a decrease in its density. The density at $350^{\circ} \mathrm{C}$ is derived from Eqs 2 and 3. And $\triangle \mathrm{L}$ is the linear expansion length, $L$ is the original length, $\beta$ is the coefficient of linear expansion, $\Delta T$ is the temperature difference, $\rho_{T}$ is the density at temperature $T, M$ is the mass of $\mathrm{Fe}-x \mathrm{Cr}-6 \mathrm{Al}$ alloy, and $V_{T}$ is the volume at temperature $T, \rho$ is the density at room temperature.

$$
\begin{gathered}
\Delta L=L \cdot \beta \cdot \Delta T \\
\rho_{T}=M / V_{T}=M /(L+\Delta L)^{3}=\rho /(1+\beta \cdot T)^{3}
\end{gathered}
$$

Figure 8 shows the Vickers hardness of $\mathrm{Fe}-x \mathrm{Cr}-6 \mathrm{Al}$ alloy at room temperature. As a general trend, the Vickers hardness of the $\mathrm{Fe}-x \mathrm{Cr}-6 \mathrm{Al}$ alloy increases with the increasing $\mathrm{Cr}$ content when the $\mathrm{Cr}$ atoms replace the $\mathrm{Fe}$ atoms in the $\mathrm{Fe}-x \mathrm{Cr}-6 \mathrm{Al}$ alloy with $11-15 \mathrm{wt} \%$.

The compressibility of FeCrAl cladding material appears to be influenced by the $\mathrm{Cr}$ content within the alloy, but the detail remains unclear and requires further study. Figure 9 shows the relationship between the $\mathrm{Cr}$ content and the compressive yield strength of the $\mathrm{FeCrAl}$ alloy at room temperature. It can be seen from Figure 9 that when the $\mathrm{Cr}$ content increases, the compressive yield strength of the $\mathrm{Fe}-x \mathrm{Cr}-6 \mathrm{Al}$ alloy increases. 


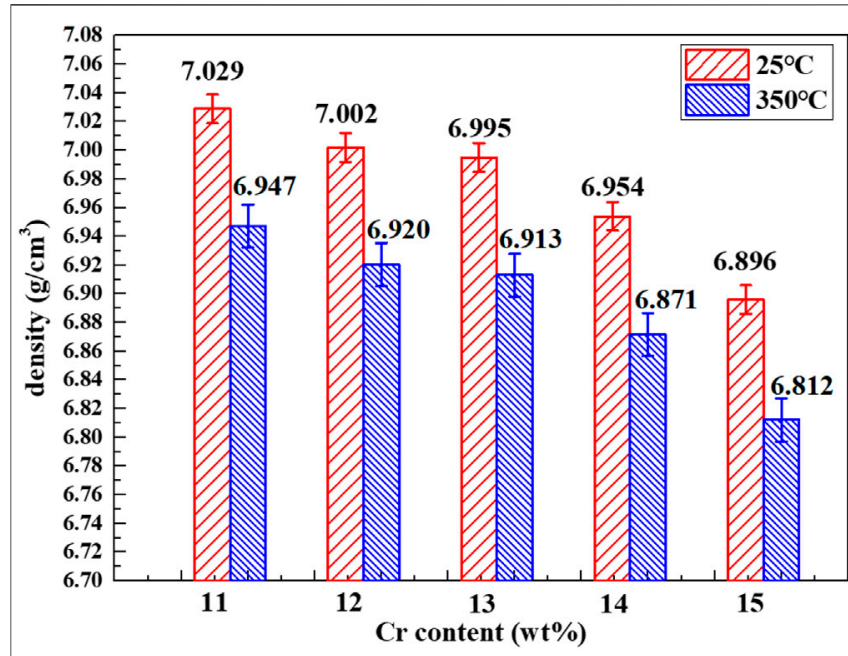

FIGURE 7 | Composition-density curves of $\mathrm{Fe}-x \mathrm{Cr}-6 \mathrm{Al}$ alloys with different $\mathrm{Cr}$ content. The density at $350^{\circ} \mathrm{C}$ is derived from the density of $\mathrm{Fe}-x \mathrm{Cr}-6 \mathrm{Al}$ alloys at $25^{\circ} \mathrm{C}$ and coefficient of thermal expansion at $350^{\circ} \mathrm{C}$.

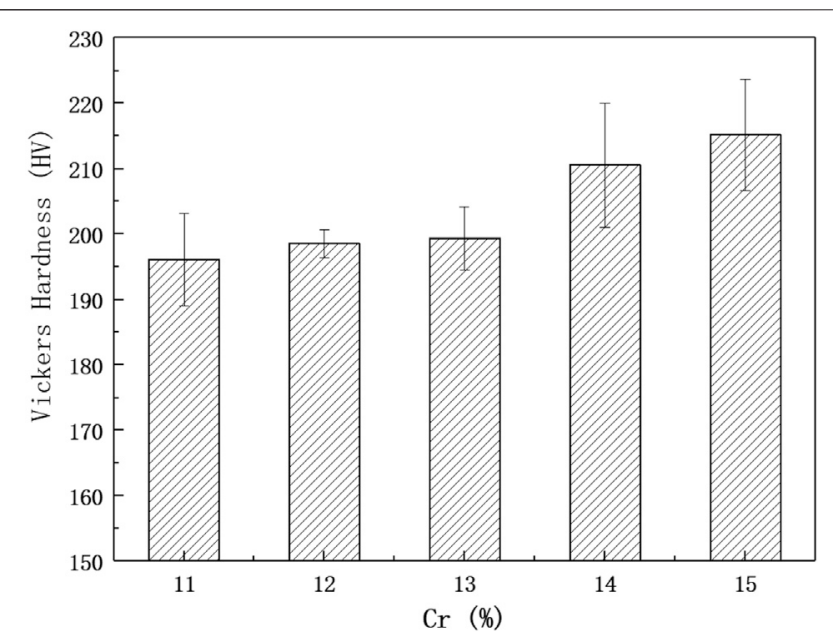

FIGURE 8 | Vickers hardness of $\mathrm{Fe}-x \mathrm{Cr}-6 \mathrm{Al}$ alloys with different $\mathrm{Cr}$ content.

The deformation mechanism of $\mathrm{Fe}-x \mathrm{Cr}-6 \mathrm{Al}$ alloy is dominated by the movement of edge dislocations at room temperature (Osetsky et al., 2014; Korchuganov et al., 2018). As the $\mathrm{Cr}$ content increases, the movement of the dislocation requires greater energy efficiency, so the compressive performance of the $\mathrm{Fe}-x \mathrm{Cr}-6 \mathrm{Al}$ alloy is improved.

\section{Thermal Performance of Fe-xCr-6Al}

Figure 10 is the curve on CTE of $\mathrm{Fe}-x \mathrm{Cr}-6 \mathrm{Al}$ alloy at $350^{\circ} \mathrm{C}$. It can be seen from Figure 10 that the $\mathrm{CTE}$ of $\mathrm{Fe}-x \mathrm{Cr}-6 \mathrm{Al}$ alloys show a positive trend with respect to the $\mathrm{Cr}$ contents. In order to understand this, simple diatomic models are built in this work. Using DFT method at the level of B3LYP/6-31G(d, p) by Gauss09
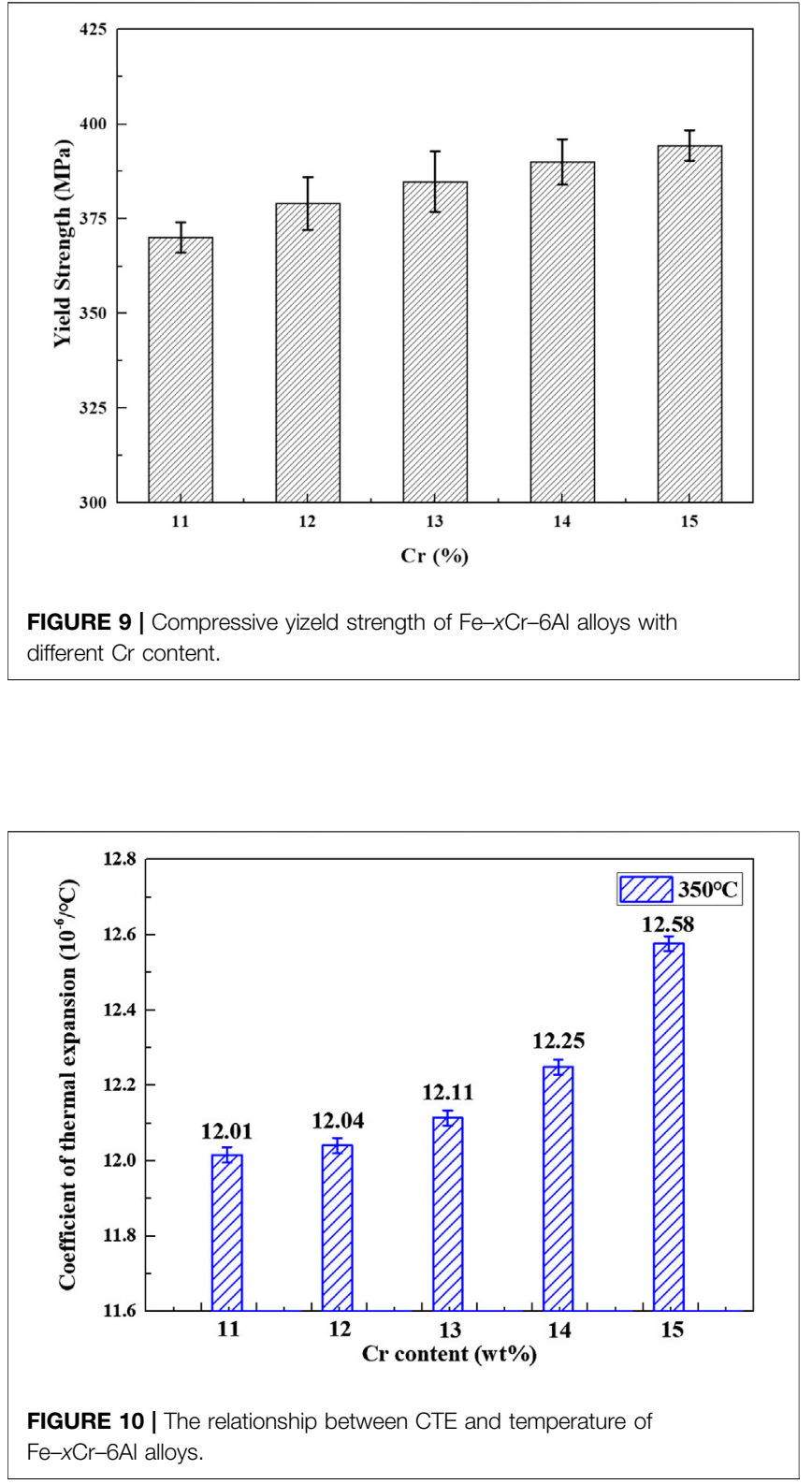

software, the relationship between the bond length $r$ and the potential energy $(\triangle E)$ of $\mathrm{Fe}-\mathrm{Fe}, \mathrm{Fe}-\mathrm{Cr}$ and $\mathrm{Cr}-\mathrm{Cr}$ are calculated as shown in Figures 11A-C. The relationship between atomic bond length and relative atomic potential energy increase rate $\left(\triangle E^{\prime}\right)$ (Figure 11D) and the relationship between atomic bond length and relative atomic bond length increase rate (Figure 11E) are established by Figures 11A-C. From Figure 11D, it is found $\Delta E_{\mathrm{Cr}-\mathrm{Cr}}^{\prime}>\Delta E_{\mathrm{Fe}-\mathrm{Fe}}^{\prime}>\Delta E_{\mathrm{Fe}-\mathrm{Cr}}^{\prime}$ when the bond length is between 0.2 and $0.4 \mathrm{~nm}$ and the bond energy required for each alloy bond growth decreases with the increase of the bond length. As a result, the increment of bond length with given energy shows an opposite trend as shown in Figure $11 \mathrm{E}$ and the rate of $\mathrm{Fe}-\mathrm{Cr}$ appears the highest. The distance between each atom in $\mathrm{Fe}-x \mathrm{Cr}-6 \mathrm{Al}$ alloys is in the range of $0.24-0.32 \mathrm{~nm}$, and the increase of $\mathrm{Cr}$ content mainly leads to the decrease of $\mathrm{Fe}-\mathrm{Fe}$ 


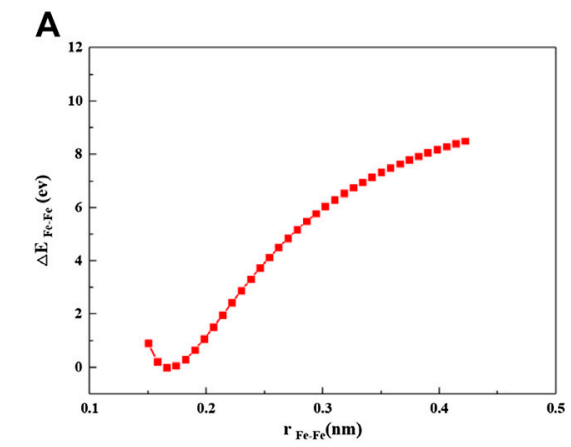

D

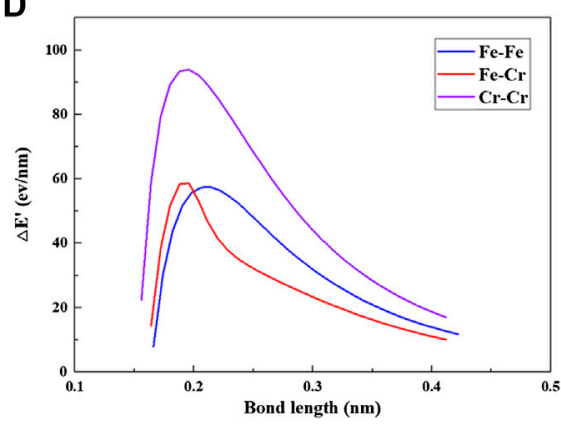

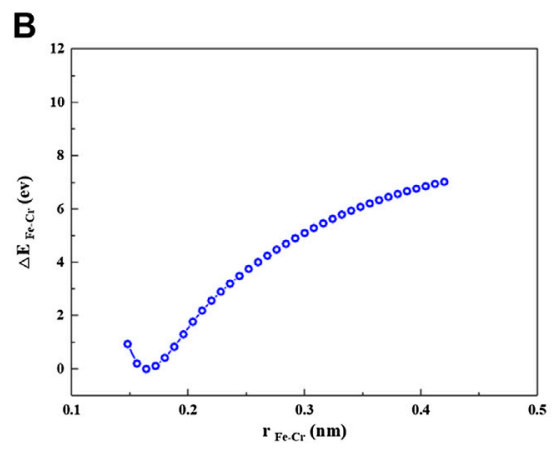
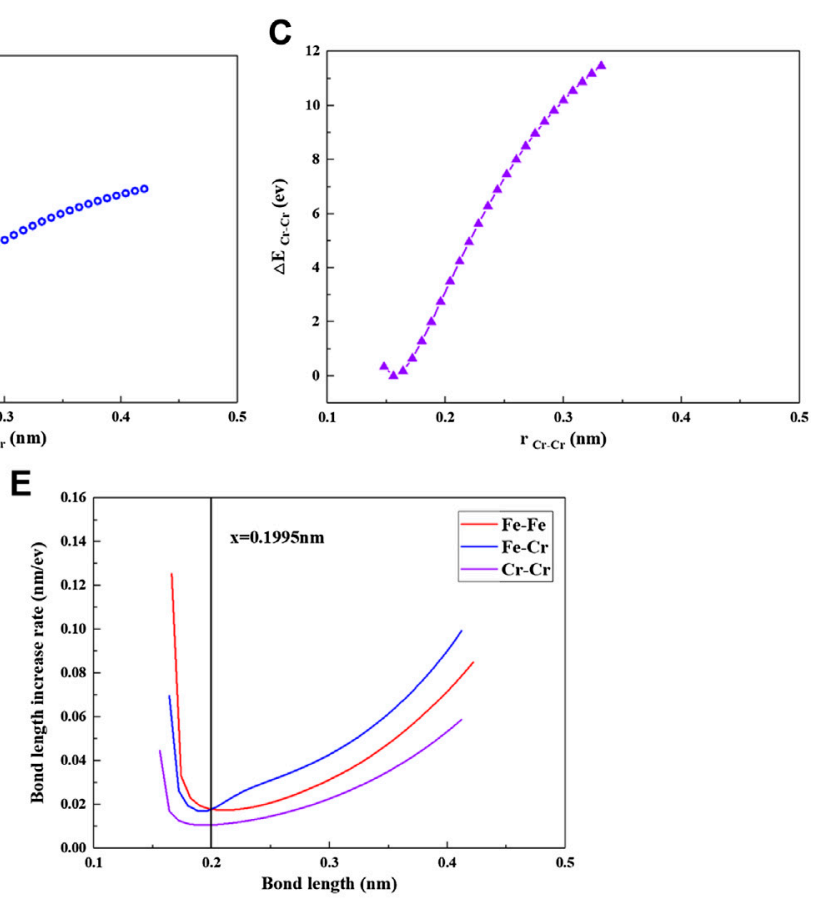

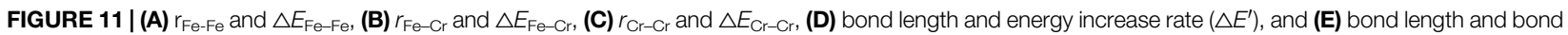
length increase rate.
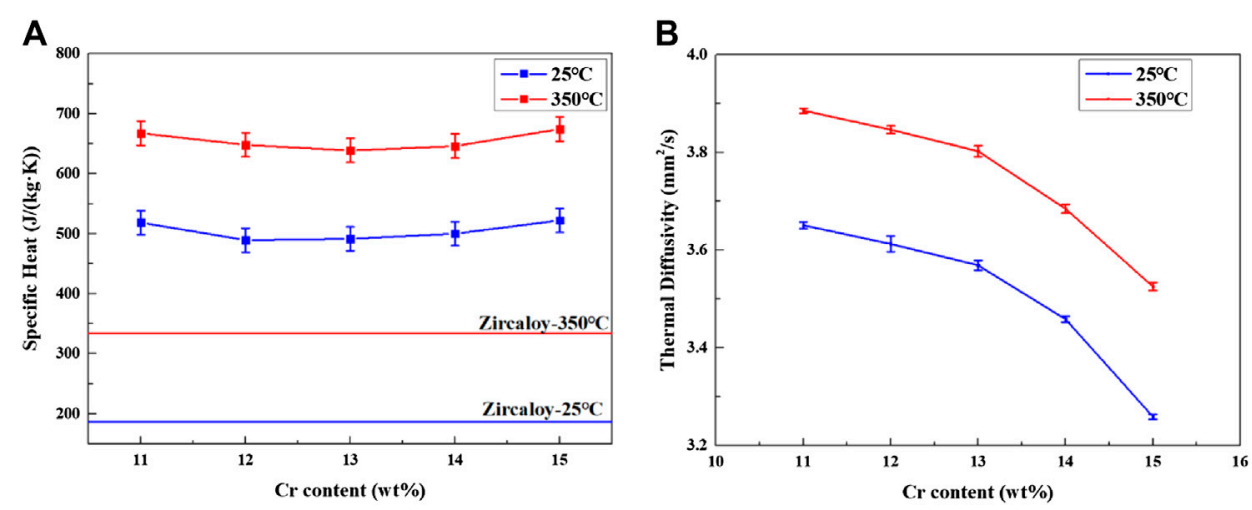

FIGURE 12 | The thermal conductivity (A) and thermal diffusivity (B) of Fe-xCr-6Al alloy with different Cr content.

and the increase of $\mathrm{Fe}-\mathrm{Cr}$ in the alloy. Moreover, since there is less segregation of $\mathrm{Cr}$ in the alloy in the range of $11-15 \mathrm{wt} \%$, the increase of $\mathrm{Cr}$ won't lead to the increase of $\mathrm{Cr}-\mathrm{Cr}$. Therefore, the increase of the $\mathrm{Cr}$ content will increase the thermal expansion coefficient of $\mathrm{Fe}-x \mathrm{Cr}-6 \mathrm{Al}$ alloys.

The specific heat and thermal diffusion coefficient of $\mathrm{Fe}-x \mathrm{Cr}-6 \mathrm{Al}$ alloy were measured by Differential Scanning Calorimeter, as shown in Figures 12A,Figures 12B. The specific heat and the thermal conductivity of Zircaloy are used as comparison with the data reported by Ott et al. (2014). It can be seen from Figure 12A that when the $\mathrm{Cr}$ content in $\mathrm{Fe}-x \mathrm{Cr}-6 \mathrm{Al}$ increases from 11 to $15 \mathrm{wt} \%$, the specific heat of $\mathrm{Fe}-x \mathrm{Cr}-6 \mathrm{Al}$ alloy decreases first and then increases. When the temperature increases from 25 to $350^{\circ} \mathrm{C}$, the specific heat of $\mathrm{FeCrAl}$ alloy increases. Compared with zirconium alloy, $\mathrm{Fe}-x \mathrm{Cr}-6 \mathrm{Al}$ alloy has a higher specific heat capacity.

The thermal diffusion coefficient of $\mathrm{Fe}-x \mathrm{Cr}-6 \mathrm{Al}$ alloy were measured by laser thermal conductivity meter, as shown in Figure 12B. It can be seen from Figure 12B that the thermal diffusivity of $\mathrm{Fe}-x \mathrm{Cr}-6 \mathrm{Al}$ alloy decreases with the increase of $\mathrm{Cr}$ element content. The thermal diffusivity of $\mathrm{Fe}-11 \mathrm{Cr}-6 \mathrm{Al}$ alloy decreases from 3.65 to $3.26 \mathrm{~mm}^{2} / \mathrm{s}$ at $25^{\circ} \mathrm{C}$. At $350^{\circ} \mathrm{C}$, the thermal diffusivity of $\mathrm{Fe}-11 \mathrm{Cr}-6 \mathrm{Al}$ alloy decreases from 3.89 to $3.53 \mathrm{~mm}^{2} / \mathrm{s}$. 


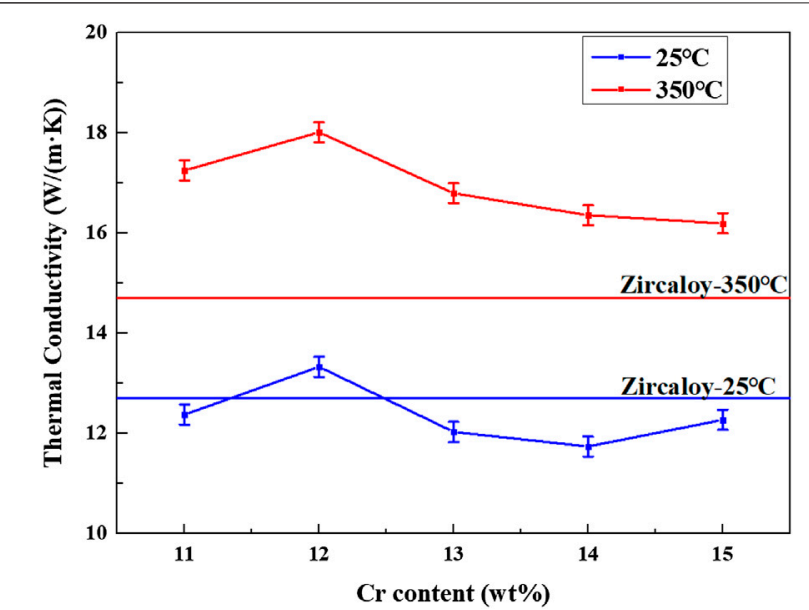

FIGURE 13 | The specific heat of $\mathrm{Fe}-x \mathrm{Cr}-6 \mathrm{Al}$ alloy with different $\mathrm{Cr}$ content. the Fe- $x \mathrm{Cr}-6 \mathrm{Al}$ alloy transfers the heat energy of the core to the cooling water more efficiently at operating temperature, which will increase the power generation efficiency of nuclear power plants.

\section{Oxidation Weight Gain of $\mathrm{Fe}-\mathrm{xCr}-6 \mathrm{Al}$ Cladding Materials}

Figure 14 shows the composition-oxidation weight gain curve of $\mathrm{Fe}-x \mathrm{Cr}-6 \mathrm{Al}$ alloy at room temperature after being oxidized in high temperature water vapor at $1,200^{\circ} \mathrm{C}$ for $4 \mathrm{~h}$. When the $\mathrm{Cr}$ content in $\mathrm{Fe}-x \mathrm{Cr}-6 \mathrm{Al}$ increases from 11 to $14 \mathrm{wt} \%$, the oxidation weight gain of $\mathrm{Fe}-x \mathrm{Cr}-6 \mathrm{Al}$ alloy increases from $0.158 \mathrm{mg} / \mathrm{cm}^{2}$ to $0.586 \mathrm{mg} / \mathrm{cm}^{2}$ for the oxidation activity of $\mathrm{Cr}$ element is higher than that of Fe element. Namely, before forming an effective $\mathrm{Al}_{2} \mathrm{O}_{3}$ protective layer, as the content of $\mathrm{Cr}$ element increases, the oxidation weight of $\mathrm{Fe}-x \mathrm{Cr}-6 \mathrm{Al}$ alloy in high temperature water vapor at $1,200^{\circ} \mathrm{C}$ increases. And then the initial total formation rate of $\mathrm{Cr}_{2} \mathrm{O}_{3}$ and $\mathrm{Fe}_{2} \mathrm{O}_{3}$ oxides increases with the $\mathrm{Cr}$ content increases. At $1,200^{\circ} \mathrm{C}$, the $\mathrm{Al}$ in the $\mathrm{Fe}-x \mathrm{Cr}-6 \mathrm{Al}$
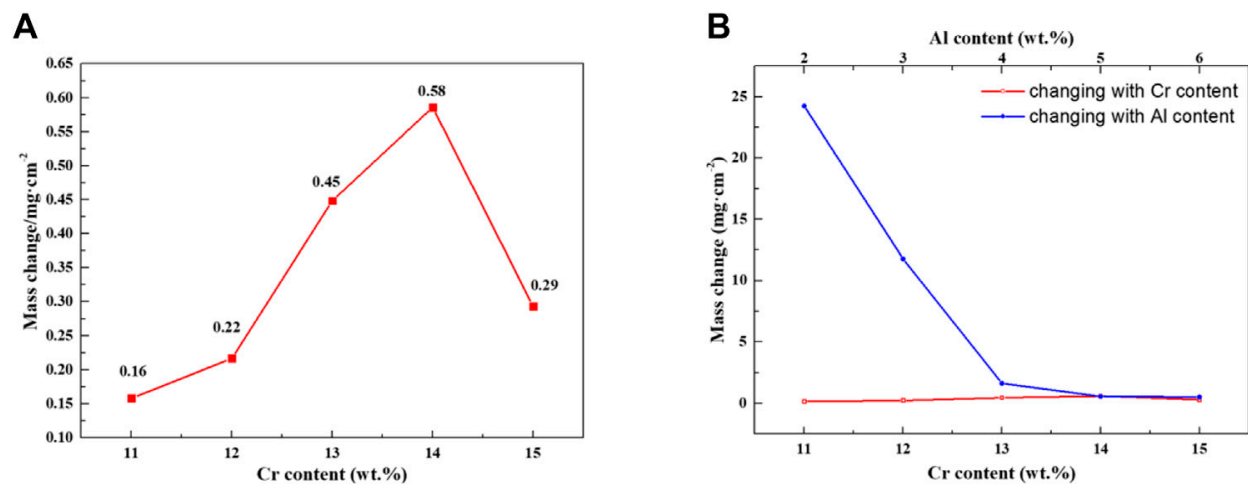

FIGURE 14 | Oxidation weight gain of $\mathrm{Fe}-x \mathrm{Cr}-6 \mathrm{Al}$ alloy with different $\mathrm{Cr}$ content after high temperature steam oxidation.

\section{Effect of Cr Content on the Specific Heat of Fe-xCr-6Al Cladding Materials}

The relationship among solid material thermal conductivity $\lambda$, specific heat C, coefficient of thermal expansion $\alpha$ and density $\rho$ is shown in Eq. 4 (Liu et al., 2019):

$$
\lambda=C \cdot \alpha \cdot \rho
$$

The specific heat and thermal diffusion coefficient of $\mathrm{Fe}-x \mathrm{Cr}-6 \mathrm{Al}$ alloy were measured by laser thermal conductivity meter, as shown in Figure 13. It found that the thermal conductivity of $\mathrm{Fe}-x \mathrm{Cr}-6 \mathrm{Al}$ alloy decreases slightly with the increase of $\mathrm{Cr}$ probably because the obstruction of $\mathrm{Fe}-x \mathrm{Cr}-6 \mathrm{Al}$ alloy's electron and phonon transport increase with $\mathrm{Cr}$ content increase. The thermal conductivity of $\mathrm{Fe}-11 \mathrm{Cr}-6 \mathrm{Al}$ alloy decreases from 13.3 to 11.7 at $25^{\circ} \mathrm{C}$. And at $350^{\circ} \mathrm{C}$, the thermal conductivity of $\mathrm{Fe}-11 \mathrm{Cr}-6 \mathrm{Al}$ alloy decreases from 18.0 to $16.2 \mathrm{~W} /(\mathrm{mK})$. It is found that the thermal performance of zirconium alloy is slightly better than $\mathrm{Fe}-x \mathrm{Cr}-6 \mathrm{Al}$ alloy at $25^{\circ} \mathrm{C}$, but at $350^{\circ} \mathrm{C}$ operating temperature, the thermal conductivity of $\mathrm{Fe}-x \mathrm{Cr}-6 \mathrm{Al}$ alloy is higher than that of zirconium alloy. That means alloy has high reducibility, which makes the rate of Al participating in the reduction reaction increase, and the $\mathrm{Al}_{2} \mathrm{O}_{3}$ film can be formed faster with the initial formation rate of $\mathrm{Cr}_{2} \mathrm{O}_{3}$. When $\mathrm{Cr}$ atoms replaced $\mathrm{Fe}$ atoms in $\mathrm{Fe}-x \mathrm{Cr}-6 \mathrm{Al}$ alloy with $14 \mathrm{wt} . \%-15 \mathrm{wt} \%$, the weight gain after oxidation of $\mathrm{Fe}-x \mathrm{Cr}-6 \mathrm{Al}$ alloy decreased from 0.586 to $0.293 \mathrm{mg} / \mathrm{cm}^{2}$. It indicates the oxidation weight gain rate can be greatly reduced when the $\mathrm{Al}_{2} \mathrm{O}_{3}$ generated is enough via reducing enough $\mathrm{Cr}_{2} \mathrm{O}_{3}$ to coat the $\mathrm{Fe}-x \mathrm{Cr}-6 \mathrm{Al}$ alloy sample. When the $\mathrm{Al}_{2} \mathrm{O}_{3}$ film formed by the reaction is sufficient to cover the $\mathrm{Fe}-x \mathrm{Cr}-6 \mathrm{Al}$ alloy sample, the anti-corrosion characteristics of the alloy can be observed.

\section{CONCLUSION}

This work mainly studied the influence of different $\mathrm{Cr}$ content on the microstructure, mechanical properties, oxidation resistance and thermal properties of $\mathrm{Fe}-x \mathrm{Cr}-6 \mathrm{Al}$ alloy. When $\mathrm{Cr}$ atoms replace $\mathrm{Fe}$ atoms in $\mathrm{Fe}-x \mathrm{Cr}-6 \mathrm{Al}$ alloy from 11 to $15 \mathrm{wt} \%$, the changes in properties of $\mathrm{Fe}-x \mathrm{Cr}-6 \mathrm{Al}$ alloy are summarized as follows: 
1. The grain size of the $\mathrm{Fe}-x \mathrm{Cr}-6 \mathrm{Al}$ alloy varies between 350 and $450 \mu \mathrm{m}$. And the prepared $\mathrm{Fe}-x \mathrm{Cr}-6 \mathrm{Al}$ alloy is still a-Fe singlephase structure, which belongs to ferrite, and won't change with the change of $\mathrm{Cr}$ content.

2. The density of $\mathrm{Fe}-x \mathrm{Cr}-6 \mathrm{Al}$ alloy is slightly reduced, its hardness will increase by $9.7 \%$, and its compressive yield strength will increase from 370 to $394 \mathrm{MPa}$.

3. The oxidation weight gains of the $\mathrm{Fe}-x \mathrm{Cr}-6 \mathrm{Al}$ alloy obtained by oxidation in a high temperature water vapor environment of $1,200^{\circ} \mathrm{C}$ for $4 \mathrm{~h}$ first increased from 0.158 to $0.586 \mathrm{mg} / \mathrm{cm}^{2}$ and then decreased to $0.293 \mathrm{mg} / \mathrm{cm}^{2}$. This is mainly caused by the combined effect of the increase of the $\mathrm{Cr}$ content leading to the increase of the initial oxide generation rate and the substantial reduction of the oxidation rate after the aluminum oxide film completely covers the $\mathrm{Fe}-x \mathrm{Cr}-6 \mathrm{Al}$ alloy.

4. The thermal expansion coefficient increase, the thermal conductivity and thermal diffusion coefficient of $\mathrm{Fe}-x \mathrm{Cr}-6 \mathrm{Al}$ alloy decrease, and the specific heat decreases first and then increases.

\section{DATA AVAILABILITY STATEMENT}

The original contributions presented in the study are included in the article/Supplementary Material, further inquiries can be directed to the corresponding author.

\section{REFERENCES}

Aghamiri, S. M. S., Sowa, T., Ukai, S., Oono, N., Sakamoto, K., and Yamashita, S. (2020). Microstructure and texture evolution and ring-tensile properties of recrystallized FeCrAl ODS cladding tubes. Mater. Sci. Eng. A. 771, 138636. doi:10.1016/j.msea.2019.138636

Chang, K., Meng, F., Ge, F., Zhao, G., Du, S., and Huang, F. (2019). Theoryguided bottom-up design of the FeCrAl alloys as accident tolerant fuel cladding materials. J. Nucl. Mater. 516, 63-72. doi:10.1016/j.jnucmat.2019. 01.002

Chen, L., Li, J., Zhang, Y., Zhang, L. C., Lu, W., Zhang, L., et al. (2015). Effects of alloyed $\mathrm{Si}$ on the autoclave corrosion performance and periodic corrosion kinetics in Zr-Sn-Nb-Fe-O alloys. Corros. Sci. 100, 651-662. doi:10.1016/j. corsci.2015.08.043

Chen, L. Y., Shen, P., Zhang, L., Lu, S., Chai, L., Yang, Z., et al. (2018). Corrosion behavior of non-equilibrium $\mathrm{Zr}-\mathrm{Sn}-\mathrm{Nb}-\mathrm{Fe}-\mathrm{Cu}-\mathrm{O}$ alloys in high-temperature $0.01 \mathrm{M} \mathrm{LiOH}$ aqueous solution and degradation of the surface oxide films. Corros. Sci. 136, 221-230. doi:10.1016/j.corsci.2018.03.012

Chen, L., Zeng, Q., Li, J., Lu, J., Zhang, Y., Zhang, L. C., et al. (2016). Effect of microstructure on corrosion behavior of a $\mathrm{Zr}-\mathrm{Sn}-\mathrm{Nb}-\mathrm{Fe}-\mathrm{Cu}-\mathrm{O}$ alloy. Mater. Des. 92, 888-896. doi:10.1016/j.matdes.2015.12.067

Dryepondt, S., Unocic, K. A., Hoelzer, D. T., Massey, C. P., and Pint, B. A. (2018). Development of low-Cr ODS FeCrAl alloys for accident-tolerant fuel cladding. J. Nucl. Mater. 501, 59-71. doi:10.1016/j.jnucmat.2017.12.035

Farmer, M. T., Leibowitz, L., Terrani, K. A., and Robb, K. R. (2014). Scoping assessments of ATF impact on late-stage accident progression including molten core-concrete interaction. J. Nucl. Mater. 448, 534-540. doi:10.1016/j.jnucmat. 2013.12.022

Field, K. G., Hu, X., Littrell, K. C., Yamamoto, Y., and Snead, L. L. (2015). Radiation tolerance of neutron-irradiated model $\mathrm{Fe}-\mathrm{Cr}-\mathrm{Al}$ alloys. J. Nucl. Mater. 465, 746-755. doi:10.1016/j.jnucmat.2015.06.023

Gamble, K. A., Barani, T., Pizzocri, D., Hales, J. D., Terrani, K. A., and Pastore, G. (2017). An investigation of FeCrAl cladding behavior under normal operating

\section{AUTHOR CONTRIBUTIONS}

PW: Methodology, Data Curation, Writing-original draft YQ: Conceptualization, Funding acquisition. WQ: Visualization, Investigation. SD: Writing-Reviewing and Editing, Resources, Software. ZL: Resources, Software. FM: Resources. XZ: Writing-Reviewing and Editing. KW: Resources, Investigation. QL: Resources. ZY: Resources. CB: Writing-Reviewing and Editing. XW: Supervision, Project administration.

\section{FUNDING}

The authors would like to express thanks to the financial support from the National Key Research and Development Program of China (Nos. 2016YFB0700100, 2016YFB0700104, and 2019YFB1901003), Zhejiang Province Key Research and Development Program (No. 2019C01060), National Natural Science Foundation of China (Grant No. 21875271), the project of the key technology for virtue reactors from NPIC, Aviation power fund (6141B090571), Heilongjiang Science and Technology Plan Project (GX17A012) and the Fundamental Research Funds for the Central Universities (3072020CF1001) and the Fund of Science and Technology on Reactor Fuel and Materials Laboratory (6142A06190208) and Key Laboratory of Superlight Materials and Surface Technology (Harbin Engineering University).

and loss of coolant conditions. J. Nucl. Mater. 491, 55-66. doi:10.1016/j. jnucmat.2017.04.039

Gong, X., Li, R., Sun, M., Ren, Q., Liu, T., and Short, M. P. (2016). Opportunities for the LWR ATF materials development program to contribute to the LBE-cooled ADS materials qualification program. J. Nucl. Mater. 482, 218-228. doi:10. 1016/j.jnucmat.2016.10.012

Guzonas, D., and Novotny, R. (2014). Supercritical water-cooled reactor materials summary of research and open issues. Prog. Nucl. Energ. 77, 361-372. doi:10. 1016/j.pnucene.2014.02.008

He, Y., Liu, J., Qiu, S., Deng, Z., Yang, Y., and McLean, A. (2018). Microstructure and high temperature mechanical properties of as-cast $\mathrm{FeCrAl}$ alloys. Mater. Sci. Eng. A. 726, 56-63. doi:10.1016/j.msea.2018.04.039

Huczkowski, P., Gopalakrishnan, S. G., Nowak, W., Hattendorf, H., Iskandar, R., Mayer, J., et al. (2015). Effect of Zr content on the morphology and emissivity of surface oxide scales on FeCrAlY alloys. Adv. Eng. Mater. 18, 711-720. doi:10. 1002/adem.201500439

Kim, H., Obulan Subramanian, G., Kim, C., Jang, H., and Jang, C. (2019). $400{ }^{\circ} \mathrm{C}$ aging embrittlement of $\mathrm{FeCrAl}$ alloys: microstructure and fracture behavior. Mater. Sci. Eng. A. 743, 159-167. doi:10.1016/j.msea.2018.11.084

Konings, R. J. M., Wiss, T., and Beneš, O. (2015). Predicting material release during a nuclear reactor accident. Nat. Mater. 14, 247-252. doi:10.1038/nmat4224

Korchuganov, A. V., Zolnikov, K. P., and Kryzhevich, D. S. (2018). Simulation of interaction of edge dislocations with radiation defects in $\mathrm{Fe}-10 \mathrm{Cr}$ alloy. J. Phys. Conf. Ser. 1115, 4-9. doi:10.1088/1742-6596/1115/5/052032

Liu, M., Brown, N. R., Terrani, K. A., Ali, A. F., Blandford, E. D., and Wachs, D. M. (2017). Potential impact of accident tolerant fuel cladding critical heat flux characteristics on the high temperature phase of reactivity initiated accidents. Ann. Nucl. Energ. 110, 48-62. doi:10.1016/j.anucene.2017.06.016

Liu, Y. F., Jia, X. J., Qiao, X. G., Xu, S. W., and Zheng, M. Y. (2019). Effect of La content on microstructure, thermal conductivity and mechanical properties of $\mathrm{Mg}$ e 4Al magnesium alloys. J. Alloys Compd. 806, 114. doi:10.1016/j.jallcom. 2019.07.267

MacDonald, P., Buongiorno, J., Sterbentz, J., Davis, C., Witt, R., Was, Gary., et al. (2005). Feasibility study of supercritical light water cooled fast reactors for 
actinide burning and electric power production. Berlin: Springer. doi:10.2172/ 835712

Maeda, T., Ukai, S., Hayashi, S., Oono, N., Shizukawa, Y., and Sakamoto, K. (2019). Effects of zirconium and oxygen on the oxidation of FeCrAl-ODS alloys under air and steam conditions up to $1500^{\circ} \mathrm{C}$. J. Nucl. Mater. 516, 317-326. doi:10. 1016/j.jnucmat.2019.01.041

Naidin, M., Mokry, S., Baig, F., Gospodinov, Y., Zirn, U., Pioro, I., et al. (2009). Thermal-design options for pressure-channel SCWRs with cogeneration of hydrogen. J. Eng. Gas Turbines Power 131, 133. doi:10. $1115 / 1.2983016$

Niu, Y., Wang, S., Gao, F., Zhang, Z. G., and Gesmundo, F. (2008). The nature of the third-element effect in the oxidation of $\mathrm{Fe}-x \mathrm{Cr}-3$ at $\% \mathrm{Al}$ alloys in $1 \mathrm{~atm} \mathrm{O} 2$ at 1,000 ${ }^{\circ}$ C. Corros. Sci. 50, 345-356. doi:10.1016/j.corsci.2007.06.019

Osetsky, Y., Khorgolkhuu, O., Samolyuk, G., Nicholson, D., Stoller, R., and Stocks, M. B. T.-A. M. M. (2014). The interaction of $\mathrm{Cr}$ and $\mathrm{Ni}$ solute atoms with core of screw and edge dislocation in bcc Fe. New York, NY: American Physical Society.

Ott, L. J., Robb, K. R., and Wang, D. (2014). Preliminary assessment of accidenttolerant fuels on LWR performance during normal operation and under DB and BDB accident conditions. J. Nucl. Mater. 448, 520-533. doi:10.1016/j. jnucmat.2013.09.052

Pan, D., Zhang, R., Wang, H., Lu, C., and Liu, Y. (2016). Formation and stability of oxide layer in $\mathrm{FeCrAl}$ fuel cladding material under high-temperature steam. J. Alloys Compd. 684, 549-555. doi:10.1016/j.jallcom.2016.05.145

Pint, B. A., Unocic, K. A., and Terrani, K. A. (2015). Effect of steam on high temperature oxidation behaviour of alumina-forming alloys. Mater. High Temp. 32, 28-35. doi:10.1179/0960340914Z.00000000058

Qiao, Y., Wang, P., Qi, W., Du, S., Liu, Z., Meng, F., et al. (2020). Mechanism of Al on $\mathrm{FeCrAl}$ steam oxidation behavior and molecular dynamics simulations. J. Alloys Compd. 828, 33-39. doi:10.1016/j.jallcom.2020.154310

Qiu, B., Wu, Y., Deng, Y., He, Y., Liu, T., Su, G. H., et al. (2018). A comparative study on preliminary performance evaluation of ATFs under normal and accident conditions with FRAP-ATF code. Prog. Nucl. Energ. 105, 51-60. doi:10.1016/j.pnucene.2017.12.010

Saowadee, N., Agersted, K., and Bowen, J. R. (2017). Lattice constant measurement from electron backscatter diffraction patterns. J. Microsc. 266, 200-210. doi:10. $1111 /$ jmi. 12529

Song, P., Morrall, D., Zhang, Z., Yabuuchi, K., and Kimura, A. (2018). Radiation response of ODS ferritic steels with different oxide particles under ion- irradiation at $550^{\circ} \mathrm{C}$. J. Nucl. Mater. 502, 76-85. doi:10.1016/j.jnucmat.2018. 02.007

Steinbrück, M., Vér, N., and Gro?E, M. (2011). Oxidation of advanced zirconium cladding alloys in steam at temperatures in the range of $600-1200^{\circ} \mathrm{C}$. Oxid. Met. 76, 215-232. doi:10.1007/s11085-011-9249-3

Sun, Z., Bei, H., and Yamamoto, Y. (2017). Microstructural control of FeCrAl alloys using Mo and Nb additions. Mater. Charact. 132, 126-131. doi:10.1016/j. matchar.2017.08.008

Sun, Z., Edmondson, P. D., and Yamamoto, Y. (2018). Effects of Laves phase particles on recovery and recrystallization behaviors of $\mathrm{Nb}$-containing $\mathrm{FeCrAl}$ alloys. Acta Mater. 144, 716-727. doi:10.1016/j.actamat.2017.11.027

Yamamoto, Y., Pint, B. A., Terrani, K. A., Field, K. G., Yang, Y., and Snead, L. L. (2015). Development and property evaluation of nuclear grade wrought $\mathrm{FeCrAl}$ fuel cladding for light water reactors. J. Nucl. Mater. 467, 703-716. doi:10.1016/ j.jnucmat.2015.10.019

Yang, Z., Wang, Z. X., Xia, C. H., Ouyang, M. H., Peng, J. C., Zhang, H. W., et al. (2020). Aluminum suppression of $\alpha^{\prime}$ precipitate in model $\mathrm{Fe}-\mathrm{Cr}-\mathrm{Al}$ alloys during long-term aging at $475^{\circ}$ C. Mater. Sci. Eng. A. 772, 138714. doi:10.1016/j. msea.2019.138714

Yano, Y., Tanno, T., Oka, H., Ohtsuka, S., Inoue, T., Kato, S., et al. (2017). Ultrahigh temperature tensile properties of ODS steel claddings under severe accident conditions. J. Nucl. Mater. 487, 229-237. doi:10.1016/j.jnucmat. 2017.02.021

Zinkle, S. J., Terrani, K. A., Gehin, J. C., Ott, L. J., and Snead, L. L. (2014). Accident tolerant fuels for LWRs: a perspective. J. Nucl. Mater. 448, 374-379. doi:10. 1016/j.jnucmat.2013.12.005

Conflict of Interest: The authors declare that the research was conducted in the absence of any commercial or financial relationships that could be construed as a potential conflict of interest.

Copyright $\odot 2021$ Wang, Qiao, Qi, Du, Liu, Meng, Zhang, Wang, Li, Yao, Bai and Wang. This is an open-access article distributed under the terms of the Creative Commons Attribution License (CC BY). The use, distribution or reproduction in other forums is permitted, provided the original author(s) and the copyright owner(s) are credited and that the original publication in this journal is cited, in accordance with accepted academic practice. No use, distribution or reproduction is permitted which does not comply with these terms. 